Henning Bergenholtz* and Uwe Kaufmann*

\title{
Terminography and Lexicography. A Critical Sur- vey of Dictionaries from a Single Specialised Field
}

\author{
1. LSP Lexicography and Terminography \\ 2. Dictionary Classification \\ 3. Dictionary Functions and Dictionary Users \\ 4. Text Reception \\ 5. Text Production and Translation \\ 6. Biotec-Lexinome \\ 7. LSP Lexicography or Terminography \\ 8. Literature
}

\section{LSP Lexicography and Terminography}

LSP lexicographers describe existing terms, they suggest a preference for specific terms, they standardise lexicographical definitions, and they propose new terms, all according to the terminology of a specific subject field. Terminographers describe existing terms, they suggest a preference for specific terms, they standardise definitions and propose new terms, too. Based on this description of virtually identical objects and aims specialised or LSP lexicography and terminography have been described as synonymous terms (Joly 1986, Bergenholtz 1995a, Wiegand 1995). This view is shared by many "LSP describers and standardisers" who regard themselves as lexicographers. Terminographers on the other hand, especially those of the Vienna School tradition, have not been known to perceive a similar relation of synonymy. On the contrary, these terminographers stress the dissimilarity between LSP lexicography and terminography, a dissimilarity which they regard not as a difference of degree but as a sweeping difference between two entirely different disciplines. When forming a contrast to terminography the general term lexicography is usually preferred to

\footnotetext{
Henning Bergenholtz

Centre for Lexicography

Handelsh $\phi j s k o l e n ~ i ~ A a r h u s$

Fuglesangs Allé 4

DK-8210 Aarhus V

HB@lng.hha.dk
}

* Uwe Kaufmann Agricultural University Afdelingen for Almen Genetik Bülowsvej 13

DK-1870 Kobenhavn V

Uwe.Kaufmann@ecoll.kvl.dk 
LSP lexicography, which may only confuse matters, rendering the impression that the difference here lies between terminography and LGP lexicography. At one time the term terminological lexicography was used synonymously with terminography. Finally, we must draw attention to the fact that some terminologists use the term terminology in general without distinguishing between terminology and the subfields of terminology. In the terminology of terminologists terminology is used to designate three different concepts (Sager 1990:3); in the lexicographical terminology we will find either three homonyms or a polysemous lexeme:

1. the set of practises and methods used for the collection, description and presentation of terms

2. a theory $[\ldots]$ for explaining the relationships between concepts and terms

3. a vocabulary of a special subject field

As we consider (1) to be a description of terminography (consistent with Felber/Budin 1989:7), we shall use this term below and summarise the arguments put forward by terminologists/ terminographers in favour of a clear distinction between terminography and lexicography/LSP lexicography in the following way:

1. Unlike lexicography, terminology deals solely with LSP language (Dubois 1979:57f., Rey 1979:239, Picht 1985:353, Thomas 1993:44).

2. Unlike lexicography, terminography uses only experts as informants, whereas lexicography will use any native speaker (Frandsen 1979:24f).

3. Unlike lexicography, terminography is computerised, its results are presented both in the form of paper dictionaries as well as on floppy disk or CD-ROM (Riggs 1989: 107).

4. Terminography prepares dictionaries for experts, lexicography for laypeople (Svensén 1992:107).

5. Terminography prepares dictionaries for text production, lexicography for text reception (Riggs 1989:90, Roald 1987:11).

6. Terminography is entirely synchronic, whereas lexicography also prepares diachronic descriptions (Wüster 1985:102).

7. Terminography is primarily prescriptive, whereas lexicography is primarily descriptive (Riggs 1989:89, Maidahl Christiansen/ Duvå/Laursen 1994:272). 
8. Terminography takes an onomasiological approach, whereas lexicography takes a semasiological approach (Riggs 1989:89, Maidahl Christiansen/Duvå/Laursen 1994:276).

9. Lexicography deals with polysemous lexemes. Terminography has no polysemy, but there may be several terms to one concept (Riggs 1989:107, Roald 1987:9).

10. In terminography all work is based on a systematic classification, this is not the case with lexicography (Roald 1987:6f, Felber/ Budin 1989:139).

11. Terminographers describe concept relations, whereas lexicographers take a linguistic approach (Felber/Budin 1989:139).

12. Unlike lexicography terminography prefers a systematic macrostructure to an alphabetic macrostructure (Roald 1987:6, Riggs 1989:91, Felber/Budin 1989:139, Picht 1985:366ff).

13. Terminography deals with concepts and terms and not with linguistic signs (Felber/Budin 1989:139).

14. Lexicography allows for specific user types and user situations, whereas terminography draws selectively upon specific knowledge profiles from a knowledge bank (Picht 1992:31).

Many of the differences stated are not genuine. You may get the impression that there is an almost frantic search for differences, perhaps in an effort to present terminography as something really unique (Bergenholtz 1995a and 1995b). All the arguments presented as typical of terminology/terminography in (1), (2), (3), and (10) also apply to LSP lexicography. The importance of (8) is not completely unequivocal, but if the meaning is almost the same as in (10) this argument also applies to LSP lexicography. (6), (7), and (9) contain no clear differences, as the arguments also tend to apply to LSP lexicography. If the arguments in (4), (5), and (14) apply to LSP lexicography in general, a difference could undoubtedly be established. As to (11) a misunderstanding is at hand; as to (12) this difference is not genuine. Only (13) contains a true difference as to choice of semiotic theory and the consideration or lack of consideration for actual user types. We will comment briefly on some of the points mentioned:

It goes without saying that LSP lexicography uses only experts as informants (2), but LGP lexicography also involves experts when dealing with words relating to a specific subject field. The preface of most LSP dictionaries and major general language dictionaries will say so. 
It is a historical fact that terminologists have put the computer to use as an aid (3) much earlier than many lexicographers, including LSP lexicographers, but today nearly the entire field of lexicography has been "computerised" as well.

A contrast may exist between the arguments in (4) and (14), but even if argument (14) is to be understood in accordance with (4), the level of fundamental knowledge of a specific subject field will be so different between various users that they will not be able to selectively draw upon specific knowledge profiles. Almost every entryword has been thoroughly dealt with in bulky dictionaries, the content of which is incomprehensible to anyone but sole experts and totally irrelevant to certain users. In our opinion information about different user situations and knowledge levels (cf. ch. 6) must be included at this point. Products of LSP lexicography are sometimes aimed at experts, sometimes at laypeople (4), sometimes they are intended for text production, sometimes for reception, sometimes for translation, often for more than one of the functions (5), but LSP lexicography often takes specific functions and user types into consideration (14).

Terminography is often prescriptive (7), but so is LSP lexicography. In some countries lexical lexicography is primarily descriptive (e.g. in Denmark). In other countries it is far more prescriptive (e.g. in Iceland). In all countries, however, LSP lexicography tends to be more prescriptive than LGP lexicography, but we have witnessed a publishing house wanting prescriptive information in an LSP dictionary removed on the grounds that it cannot be the business of a dictionary to inform whether a certain usage of a word is wrong or not. In a common language context this may be open to discussion, but not in an LSP language context.

There is no distinctive difference between lexicography and terminography in terms of conception and treatment of polysemy and homonymy (9). Here we might add that a number of common language dictionaries actually do exist which in principle do not offer the possibility of polysemy, but lemmatise each polyseme in different semantic fields, e.g. Schumacher (1986). Major general language dictionaries will usually give the different meanings of a certain lexeme within the same dictionary article, but in an LSP language context this argument is weak if dealing with a single-field dictionary or a subfield dictionary. The example from Roald (1987:9) regarding the expression morphology is 
not polyseme at all in neither a linguistic, nor a medical, nor a geological dictionary. On the contrary, there is only a small degree of polysemy within a wide number of subject fields. In KAUFMANN/ BERGENHOLTZ, for instance, out of 2,500 dictionary articles only three have more than one meaning.

Many LSP dictionaries may be criticised for treating the single LSP terms in an isolated manner (10), and rightly so. To work on the basis of a systematic classification has not been patented by terminographers, but has been demanded and also put to use by LSP lexicographers (e.g. Pedersen 1995).

The nature of linguistic methods in lexicographical work is certainly open to discussion, but the description of concept relations and projections (11) or systematic relations must and should be dealt with not only by terminography, but also by (LSP) linguistics.

In a way it is somewhat surprising that the macrostructural argument is emphasised so strongly by terminographers (12), when at the same time they rightly point to other media than paper dictionaries. On a CDROM access structure is crucial to the user, whereas macrostructure is of no further importance. Naturally, you can give access to lemmata within the same node of the systematic classification, or you can provide a few, all of, or some of the dictionary articles directly relating to the subject field together with the article requested. When dealing with paper dictionaries there is no real contrast either. There is a wide number of thesauruses and systematically constructed encyclopaedias. In practise, both an alphabetic and a systematic macrostructure have advantages as well as disadvantages (Nielsen 1995). It may be more lucrative to choose a partly systematic macrostructure, if a major LSP dictionary is published in smaller parts over a number of years. In this case you would benefit from having a systematic basic classification, sorting out the specific paragraphs alphabetically (Wüster 1936:167). The mixed macrostructure may also be lucrative when dealing with single volume dictionaries. It was the structure most widely known in the LSP dictionaries of the Middle Ages, and it is also found in recent single volume dictionaries, e.g. in the German monolingual valency dictionary mentioned above (SCHUMACHER). In our opinion, the crucial aspect is not the manner of presentation, but the methodical approach during the preparation of LSP dictionaries, in which a systematic classification is an important prerequisite for absorbing the information 
relevant to the subject field. Here, LSP metalexicography is in total accordance with the apostle of the terminologists: "bei der Sammlung der in ein Fachwörterbuch aufzunehmenden Wörter kann man eigentlich gar nicht anders vorgehen als systematisch" (Wüster 1936:137).

When speaking of semiotic theory and the theoretical language connected to this, we encounter the only aspect which clearly distinguishes LSP lexicography from terminography (13). Whereas lexicographers speak of lemma, dictionary article and linguistic sign with content and expression, terminologists speak of independent concepts and expressions. Since both objects, methods and aims are largely identical for terminography and LSP lexicography, we believe that this is a typical example of two disciplines competing for the same resources and the same impact.

\section{Dictionary Classification}

Dictionaries are traditionally divided into language dictionaries, encyclopaedias and encyclopaedic dictionaries. This classification is used most consistently in a librarian context (Andersen 1990). The argumentation is more or less the following: Language dictionaries provide information about the language and only about the subject field in as far as this is necessary to the correct usage or understanding of linguistic expressions. Encyclopaedias, however, provide information about things or about a subject and only about the language in as far as this is necessary to the understanding of the subject matter. Finally, there are encyclopaedic dictionaries which aim at being both language dictionaries and encyclopaedias. The librarian classification has been adopted in the preface of many dictionaries and has also been used in a variety of modifications in metalexicographical literature, albeit in such a way that the encyclopaedic dictionaries have been projected to either the language dictionaries or the encyclopaedias. To illustrate this we may take the classification suggested by Schaeder (1994:22): 


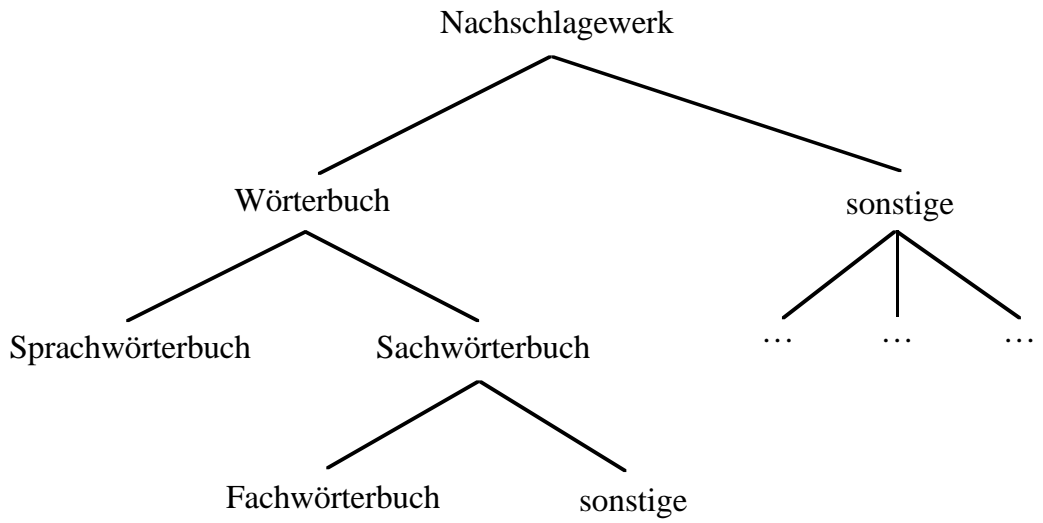

To our knowledge this classification is really based on a division between common and specialised language. According to Schaeder's extended classification there are language dictionaries which belong to the subcategory of LSP dictionaries:

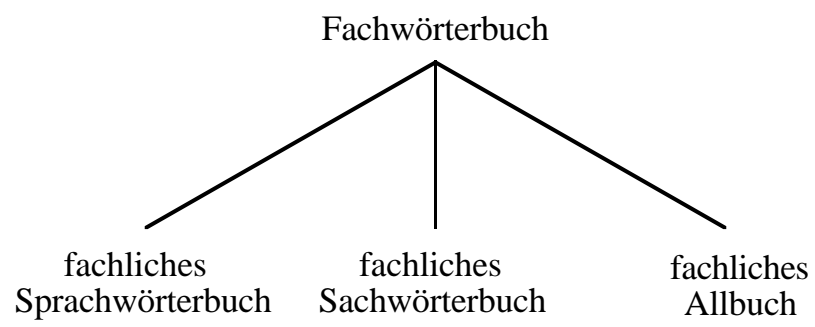

Here, Schaeder refers to Wiegand (1988) who uses and defines the dictionary types mentioned, but in an entirely different manner, since LSP dictionary in this case is not a category of its own as part of the group of encyclopaedias, but corresponding with the non-standardised usage is used both about language dictionaries, encyclopaedias and encyclopaedic dictionaries. They can be separated according to their respective genuine purposes: 


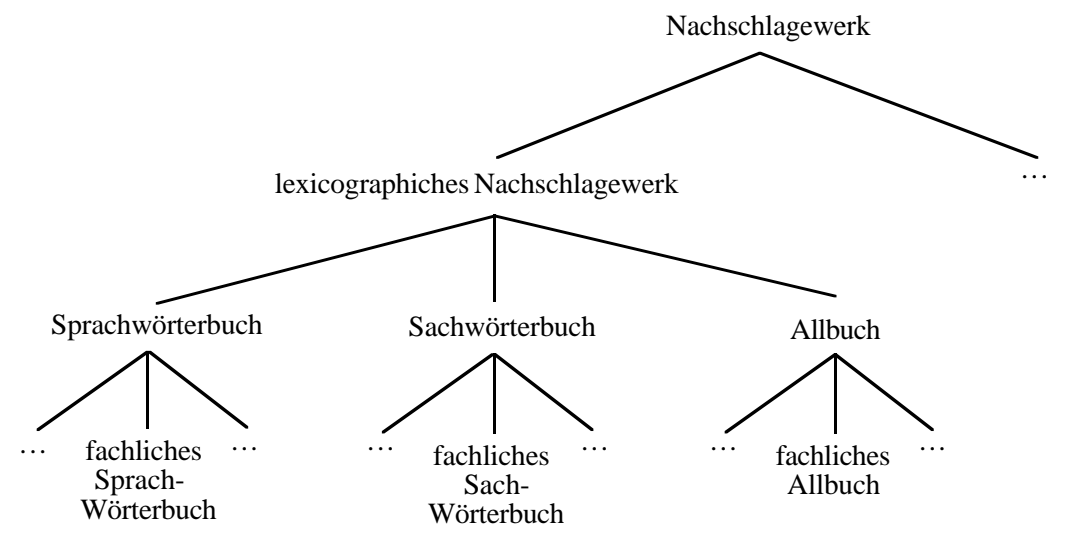

Admittedly, we adopted this classification as part of the description in the preface of KAUFMANN/BERGENHOLTZ. In principle, we wish to maintain this division, yet justify it somewhat differently to how Wiegand did, as we wish to build more conclusively on the genuine function of dictionaries, namely the functions that a reference book may fulfil or intends to fulfil.

\section{Dictionary Functions and Dictionary Users}

Wiegand's analysis presumes the division between linguistic and nonlinguistic objects (Wiegand 1988:776f), i.e. between information about the qualities of LSP terms and information about specialised objects (Wiegand 1994:107f). At first, this description reminds you of the classification of libraries. It is an entirely different classification, though, with completely different arguments and completely different results. This is evident from the dictionary quotations given, since extracts from monolingual specialised dictionaries are given for all three basic types. The difference between the various dictionaries is what they intend to inform about, not which information type they contain. We consider this basic concept to be very lucrative to the metalexicographical discussion as well as to the preparation of actual dictionaries. A user may need to know about the qualities of a specific object, but in our opinion the interpretation of this is too unspecific. It is quite obvious that dictionary users may need to gain information 
about the subject matter. Things get clearer if you determine the two basic needs as text-dependent and text-independent use of lexicographical and non-lexicographical reference books. Reference books are traditionally used for a number of basic functions, cf. below (in which $\mathrm{L} 1$ = native language and L2 = foreign language):

1. reception of L1-texts

2. production of L1-texts

3. reception of $\mathrm{L} 2$-texts

4. production of L2-texts

5. L1 $\rightarrow$ L2 translation

6. $\mathrm{L} 2 \rightarrow \mathrm{L} 1$ translation

7. acquisition of encyclopaedic information

8. acquisition of linguistic information

Functions 1-6 are text-dependent, whereas 7-8 apply to text-independent functions; 8 is not relevant in this connection as function in its own right and 7 is considered in 1-6.

This description does not imply the necessity of a separate dictionary for each of the functions mentioned. On the contrary, most dictionaries are multifunctional, as they intend to serve several functions simultaneously. This is done in LGP dictionaries (which include common language only), in single-field or multi-field dictionaries (which include one or more specialised languages), and in general language dictionaries (which intend to include both common language and the most important parts of the specialised languages). A multifunction is often intended in terms of knowledge requirement, which may be described more or less adequately by the terms laypeople, semi-experts, and experts. Whether this sort of multifunction is really appropriate will be discussed in the following chapters.

As stated above the opinion presented here leads to a classification of reference books which differs in theory as well as practise from the library directed differentiation based on information categories. We consider it to be compatible with Wiegand (1988) and (1994). 


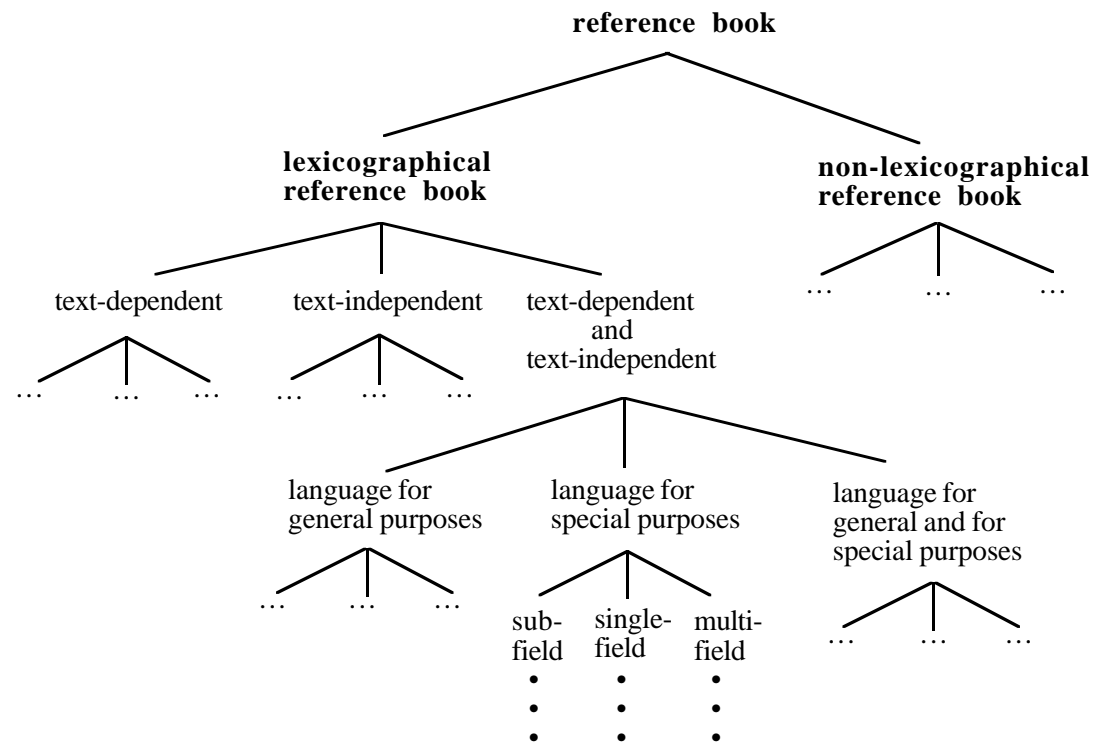

To each of the lower nodes of this graph (language for special purposes) you have to add a division into knowledge levels which according to subject field and intended user functions may be more or less finemeshed. The minimum requirement would undoubtedly be a division into laypeople, semi-experts and experts.

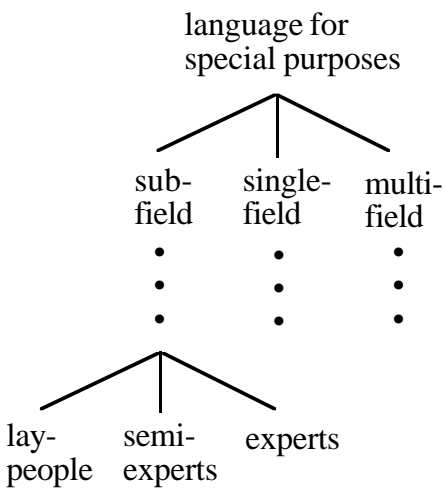


We will not enter into a discussion as to how available dictionaries may be adopted into this classification (cf. Bergenholtz 1996). We will concentrate on the utility value of available terminological and lexicographical reference books within a specific field, namely that of biotechnology. This area is defined in various ways. We presume the description presented by Dreux de Nettancourt in 1975. He identified three main areas of the 'new biology': enzyme technology and bioreactors, transfer of genetic information between organisms and the molecular understanding of disease. Using this definition with special emphasis on gene technology we have selected some dictionaries for the following discussion.

\section{Text Reception}

There is an old tradition of differentiating between laypeople and experts, but a much more detailed classification can also be made (Kalverkämper 1990). In this context, i.e. the evaluation of dictionaries, in which information concerning text reception on biotechnological problems can be found, we will adopt a rather rough classification, which distinguishes between laypeople, semi-experts, and experts. By laypeople is meant potential dictionary users who have no knowledge of the basic theories of biotechnology, or the basic knowledge only, which corresponds with the general understanding with the part of the population that has obtained a higher education. We have chosen to make this description rather vague and it covers a wide range of knowledge. The group must be differentiated from the group of semi-experts who also constitute a heterogeneous group, but on a higher level of knowledge. These are experts from other related subject fields, in this case physicians, biologists, biochemists, veterinary physicians, etc., and such workers of the public and private sector who are confronted daily by biotechnological information. They may be general advisers on science and technology whose daily job it is to advise politicians on a municipal and county level. They may also be journalists at local or national newspapers who are confronted with this controversial subject on a regular basis. One can also imagine certain politicians and other opinion leaders to have made themselves so familiar with biotechnology that they may be regarded as semi-experts. Usually, however, these groups - like many journalists - would be counted as educated laypeople at best. Finally, in terms of biotechnological subfields which 
are wide apart from the specialised knowledge of an expert, biotechnological experts must also be described as semi-experts. A true expert will have no reception problems within his own field. He may have to acquire new knowledge, but he is not likely to find this in any lexicographical dictionary. Where semi-experts and experts tend to read English specialist literature and thus may encounter reception problems of a linguistic nature, the interested layman will usually be confronted with native language texts (L1-texts) and thus consult an L1-dictionary. Apart from this, the educated layman may read periodicals or books on the subject and thus may need the assistance of an encyclopaedic L2 -> L1-dictionary.

Daily any layman will hear an expression from the biotechnological world in the paper, on radio or television. It is an area which develops constantly and also an area which makes frequent headlines in the news, since some people are fascinated by the new technological possibilities while others are alarmed or feel insecure. When a biotechnological layman hears or reads an expression like this he may look for further information about the expression that he either does not understand or of which he is uncertain. In the following we have consulted some major dictionaries and encyclopaedias for a few important terms. There are many dictionaries available to laypeople, including general language dictionaries, and minor and major encyclopaedias. We have consulted some of these books for terms which you may encounter in the daily paper or on television: gene, chromosome, DNA, gene modification, amino acid, enzyme and bacteriophage. Some of these terms are absolutely central to the ongoing discussion, others are somewhat less important, but not less relevant; they may, for instance, appear in connection with the marketing of biotechnological products. When evaluating the single dictionary articles we will focus on three criteria: Is the content of the article correct? Is the information relevant? And is the information comprehensible to the user group in question?

Monolingual dictionaries often include biotechnological entries, but besides being extremely few in number they appear to be the result of a random selection, and though apparently comprehensible, the information content is often downright wrong, cf. the article gene from HARRAP: 
gene Your genes are the parts of the cells in your body responsible for passing on some of your physical characteristics to your children.

The definition is comprehensible, but wrong in several ways. Judging from this text the layman has to assume that genes only exist in humans. Furthermore, the dictionary user is told that genes are strictly something which is passed on from one generation to the next, whereas the activity of genes, which is vital for sustaining the complicated biochemical instrument inside living beings, is totally overlooked.

It is almost to easy to find misleading information in dictionaries for laypeople; COBUILD states that genes exist in living things only, thereby wrongly precluding the fact that genes exist in vira:

gene A gene is the part of a cell in a living thing which controls its physical characteristics, growth, and development. Genes can change and reproduce themselves and they are passed on from one generation to another, for example from parents to their children.

However, the short description of the gene functions in COBUILD is informative and easy to understand. The same goes for the article in DuDEN-GwB which does not mention the fact that genes are passed on from one generation to the next:

Gen in den Chromosomen lokalisierter Träger einer Erbanlage, eines Erbfaktors, der die Ausbildung eines bestimmten Merkmals bestimmt, beeinflußt; Erbträger.

Genes are located on the chromosomes. The term appears frequently in the media, e.g. in connection with gene therapy which is a way of treating hereditary diseases by alterating the chromosomes and thus the balance between the remaining genes found on the chromosomes. A layman may want to get more detailed information about the nature of chromosomes and the functions performed by these. LONGMAN Culture states the following:

chromosome a threadlike object found in all living cells, which passes on and controls the nature, character, etc. of a young plant, animal, or cell.

The text is misleading, because it gives the indication that chromosomes are found exclusively in young plants, animals, or cells. Naturally, they are also found in older plants and animals, but not in bacteria, since bacterial chromosomes are not regarded as having a threadlike 


\section{4}

structure. Furthermore, the user is not given the important piece of information that chromosomes actually carry the genes. The following article from DUDEN-GWB is not directly misleading, but linguistically almost incomprehensible because of the rugged language. Besides, it is too complicated for a layman in terms of specialised language:

Chromosom in jedem Zellkern in artverschiedener Anzahl u. Gestalt vorhandenes, das Erbgut eines Lebewesens tragendes, fadenförmiges Gebilde.

It is possible, however, to explain these correlations in a way which is both comprehensible to laypeople and yet gives the relevant information. An example of this can be found in Heritage SCIENCE:

chromosome any of the threadlike bodies found in the nucleus of a cell that appear when the cell divides. Chromosomes are derived from the parents and carry the genes that determine heredity. The genetic material in each chromosome is a long polynucleotide strand of DNA in association with protein.

In major CD-ROM encyclopaedias, e.g. GROLIER and ENCARTA, you may also find explanations which are comprehensible to laypeople, yet usually not as brief as the example above. The description of DNA in ENCARTA, for example, comprises 14 pages when transferred to the printer. Consequently, the user who wishes to find a concise explanation must surf around on the CD-ROM for a longer period of time and may have to read his way through several pages. To a semi-expert the information given is usually not so precise as to make it totally relevant. Besides, just like the layman, the semi-expert often has to read many screen pages or surf around before managing to find all of or some of the wanted information. In other words, you might say that available major CD-ROM encyclopaedias do offer the layman adequate information, but the search itself may be time consuming, since the medium elaborates very quickly on a wide number of available information which is not central to the understanding of the matter. If such CDROM editions were to foresee different types of explanations of the same matter (cf. suggestion in ch. 6), this would be an advantage.

With very few exceptions the molecular basis of the structure and function of genes are attached to the world's biggest biomolecule: DNA, i.e. deoxyribonucleic acid. The expression is known in the media and is usually associated with the alteration of the molecule performed 
in the lab by biotechnologists. To the user who wishes to obtain more information on this biochemical key molecule, ordinary dictionaries would be the immediate source of information, but this is not done without certain problems. In Harrap neither DNA, deoxyribonucleic acid nor nucleic acid is found as an entryword. In DUDEN-GwB you search in vain for $D N A$, but under $D N S$, the earlier German name for $D N A$, you find a reference to the antiquated name Desoxyribonukleinsäure. You cannot find the now common name Deoxyribonukleinsäure. Thus, it requires a great deal of insight to get on the track of DNA. The explanation itself is misleading, since DNA presence is mentioned only in connection with plants and animals. The amount of DNA found in bacteria and vira is not mentioned at all. In CoBUILD DNA is found without difficulty. The text is comprehensible, but the specification of DNA presence is misleading, as the article indicates that DNA is found in the centre of the cells of living things which must be understood as higher organisms. Thus, the presence of DNA in bacteria and vira has been overlooked.

Gene modification, gene manipulation, gene splicing or genetic engineering, all of them synonymous terms, are absolutely central in the public debate. Especially in the light of the first "gene spliced product", gene modified tomato purée, being sold in England since the beginning of 1996, which product is also marked by this term on the declaration of contents, incidentally by an agreement between the producer and various distributors. If a purchasor of such a product tries to look up one of these terms in his dictionary, in most cases he will be disappointed: It is not found in COBUILD, HARRAP or LONGMAN CulTURE as an entryword. A few dictionaries do give the term, in this case through a comprehensible and even correct explanation, e.g. in HERITAGE SCIENCE both under gene-splicing and genetic engineering, and in DUDEN-GwB under Genmanipulation.

Some laypeople may assume that an enzyme is a component of detergents, but if you come across the term in a biotechnological context, in DudEN-GwB you will find the following explanation:

Enzym in der lebenden Zelle gebildete organische Verbindung, die den Stoffwechsel des Organismus steuert; Ferment.

This explanation is comprehensible, but not entirely correct, as enzymes do not control biochemical processes, but influence the reaction 


\section{6}

rate of these. In LONGMAN CULTURE the explanation is comprehensible, but still it manages to present three mistakes in four lines of a narrow dictionary column. From the explanation you get the impression that just a few living cells produce and contain enzymes. This is wrong, since all life depends on the presence of enzymes. Furthermore, explanations indicate that enzymes in plants and animals may induce the biochemical processes of these to happen with increased speed. Enzymes will always increase the rate of a reaction. Finally, enzymes are found not only in plants and animals, but in bacteria also.

enzyme a catalyst produced by certain living cells, which can cause chemical change in plants or animals or can make these changes happen more quickly, without being changed itself.

As a counterweight to these critical remarks we must add that it is possible to find articles in almost all dictionaries which are both elegant, well-defined as well as correct and relevant. This is the case of the lexicographical definition in OXFORD ENCYCLOPEDIC DiCTIONARY:

enzyme any of a class of large molecules, consisting entirely or chiefly of protein, found in all cells and essential to life, that act as catalysts of biochemical reactions in all living organisms. They may work within a cell or (as with digestive enzymes) outside it. The shape of each enzyme is such that it catalyses only a specific type of reaction.

Generally, however, you cannot rely upon the information of reference books for laypeople. This is evident in connection with bacteriophage. The first two examples are taken from Heritage SCIENCE and BrockHAUS/WAHRIG, resp.:

bacteriophage a virus that destroys various bacteria, normal-

ly present in the intestines, blood, etc.

Bakteriophage bakterienzerstörendes, virusartiges Gebilde

It is not correct to say that bacteriophages destroy bacteria. They attack bacteria. More precisely, bacteriophages are vira whose host cells are bacteria, and sometimes they destroy their hosts. But general language dictionaries do not only copy information from each other or from the more reliable specialised reference books, where such exist, they write their own new, but still incorrect articles, cf. a particularly misleading article in DuDEN-GwB, a monolingual German dictionary in eight volumes: 
Bakteriophage virenähnliches Kleinstlebewesen, das Bakterien vernichtet

The objections raised above are also valid here. Add to this, it is wrong to say that bacteriophages are "Kleinstlebewesen". They have never lived.

Unlike reference books for laypeople, dictionaries intended for semi-experts are usually written by molecular biological experts and thus only in exceptional cases contain inaccuracies as to specialised terms. A criticism of these works would be based on the fact that several of them comprise less than 1,000 terms and thus offer only the terms most central, but perhaps not always the terms of which a semiexperts may feel unsure. Furthermore, you have to notice that a large part of these works are in English, especially American English. This may be sufficient for semi-experts, as semi-experts often read texts in English, but such dictionaries offer no help to the semi-expert who does not have English as his mother tongue and who may need to produce a text in or translate a text into or from his native language.

\section{Text Production and Translation}

The semi-expert who works as an adviser in the public sector must orally or in writing - be able to explain a problem relating to a certain subject field in such a way as to make it comprehensible to a layman. This explanation must be accurate, but not necessarily very detailed. If there is a need for a more in-depth illustration of a problem, the semiexpert may have to turn to specialised literature which at times may not be easily obtained. For this the semi-expert will need an explanatory dictionary which, apart from the more important terms, contain more peripheral terms as well. There are a number of biotechnological dictionaries which are quite satisfactory in fulfilling the requirements of a specialised field in order to assist the semi-expert, but hardly any of them offer enough assistance, as they contain a too limited number of entrywords. Thus, explanations of these terms are not only lacking, but information on orthography, including the use of hyphens etc., and grammatical usage are nowhere to be found. On the whole, available dictionaries offer only a few explicit grammatical information items and almost no implicit collocational information, i.e. information about the word combinations surrounding a specific term. Examples of such 
dictionaries are Agriculture (appr. 2,500 entries), Biotechnology FROM A to Z (250 entries), BioteChNOLOGY GlosSARY (700 entries), Brand (600 entries), CoOMBs (4,700 entries), Glossary of BiotechNOLOGICAL TERMS (239 entries), Oliver/WARD (600 entries), WALKer/ Cox (1,530 entries). In principle, there is a wide number of implicit grammatical and collocational information items in the encyclopaedic explanations and in the quotations given by e.g. Heritage ScIENCE. In one respect, general language dictionaries such as DUDEN-GwB and COBUILD are better suited as a text production tool than the monolingual biotechnological dictionaries, as they will usually contain more explicit grammatical information items. These dictionaries, however, do not give the relevant collocational information items.

The latter problem is even bigger in terms of translation. Available dictionaries are not very well suited for translation purposes. Specialised bi- and multilingual dictionaries are usually mere word lists with lemmata in the source language, which are accompanied by their foreign-language equivalent(s). Providing neither encyclopaedic nor grammatical nor collocational information, such dictionaries at best confirm the expert's own assumptions, but layman and semi-expert alike will find them unsuitable for reception and translation purposes. Several equivalents addressed to the same lemma pose a special problem, as the layman translator will be in no position to know whether or not this is a case of full synonymy (BABEL et al. 1991):

biotin Biotin, Vitamin $\mathrm{H}$

biotinylated DNA biotinylierte DNA, mit Biotin markierte DNA

\section{biotop Biotop}

biotransformation Biotransformation, biologische Stoffwandlung

This is the case of the typical bilingual LSP dictionary of which there is a wide number, e.g. SCHMIDT/FuKUI and LH. But a very few, such as KUCERA, contain some encyclopaedic information and rather explicit grammatical and some collocational information items. Two of the dictionaries which apart from information on equivalence also contain several types of encyclopaedic information are more interesting.

Glossary of Biotechnological TeRMs comprise seven languages: American English, French, German, Japanese, Portuguese, Russian, 
and Spanish. There are brief, well-written and accurate lexicographical definitions in each language which are all translations of originally English texts. An index allows you to get to and from the languages stated. The preface of the dictionary states that it aims to contribute as a translation tool which for several reasons it cannot do this without restrictions. First of all, it contains no grammatical and collocational information, and secondly, there are only 239 terms in all which is absolutely inadequate in any translation situation. Finally, we may add that the dictionary considers itself to be a contribution to standardising specialised language within the framework of IUPAC (International Union in Pure and Applied Chemistry). With as little as 239 entries this objective can be fulfilled in a modest way only.

According to the preface of the dictionary of 1995 above this is the first biotechnological dictionary with this number of languages, but the editors must have overlooked BIOTECHNOLOGY GLOSSARY of 1990, which was published somewhat earlier by the European Commission with the intention of procuring a translation tool. This dictionary is about three times the size of the dictionary above and does also give lexicographical definitions. However, these are not given every time and there are no translations, since defining quotations are chosen in the various languages. The result is a certain irregularity, since some of the definitions are very thorough, mostly aimed at semi-experts, whereas others are very brief and easy to understand:

EN structural gene

RF Rieger Genetics

DF Any gene (representing a unique segment of geneticmaterial) that determines the primary structure (the aminoacid sequence) of a polypeptide by genetic transcriptionand genetic translation of the genetic code contained inits nucleotide sequence.

FR gène de structure

RF Biofutur 1/85 p.32

DF Gène qui contient l'information nécessaire à la synthèse d'une protéine et qui est exprimé à l'aide de l'opérateur et du promoteur au sein d'une unité de régulation dite opéron.

DE Struktur-G

RF Spiegel 52/82

DF Strukturgene codieren für die Primärstruktur der Enzymproteine. Für das An- und Abschalten der Funktion der 
Strukturgene ist der Operator verantwortlich. Der Promotor ist der Startpunkt der RNS-Synthese. Diese drei Gentypen bilden zusammen eine Steuereinheit die Operon heisst.

\section{IT gene strutturale}

RF FAST Bio, p.159

NL structurgen(1); structureel gen(2)

RF $\operatorname{COM(79)793(1);~Biotechnologie~Teleac,~p.75(2)~}$

DA struktur-gen(1); strukturelt gen(2)

RF Genetisk ordb.; p.7(1); Claus Christiansen(2)

ES gen estrutural

RF Invest. y Ciencia 4/85, p.9

PT gene estrutural

RF Enzimas, p.131

El dogiks gonidio

RF Mourkishz: Biol. Chmeia, sel.259

At this point we wanted to present the definition of gene, but the term is nowhere to be found in this dictionary as a general term, only as a part of 22 compounds such as gene amplification and the structural gene quoted here. The English definition (marked by DF) is correct, incidentally it has been taken from one of the best genetic dictionaries (RIEGER et al. 1991) which is designed for experts and quoted here from the 1976 edition. The French definition is too narrow, since it comprises structural genes in bacteria exclusively. The German definition taken as a quotation from the weekly Spiegel is very close to the French definition, but has clearly been written by a layman who is not quite in control of the terminology required. Because of the inaccuracy relating to the subject field, the lack of grammatical and collocational information and most particularly the lack of lemmatisation of the main entryword gene, this dictionary cannot fulfil the needs of a translator of biotechnological texts to the full. The choice of some of the terms is not convincing either: The common phrase in German is not Struktur-G, but Strukturgen (as stated in the definition), in Danish it is neither struktur-gen nor strukturelt gen, but simply strukturgen. By often stating several equivalents the dictionary - also corresponding with the terminographical background - does not fulfil the standardising function that such a dictionary may be expected to aim for. 
The function "translation" is connected to a somewhat complicated systematic macrostructure:

\begin{abstract}
"This glossary was originally conceived as an aid to translators faced with technical texts relating to biotechnology. [...] With this in mind it was decided to subdivide the work into a series of chapters, each dealing with a field in which biotechnology has made particularly spectacular inroads. In addition, one chapter has been devoted to the basic terminology of molecular biology, which constitutes the foundation of biotechnological research." (English Introduction, p. 1).
\end{abstract}

The systematic structure of the dictionary is based on the basic area(s) of molecular biology and eight other special areas derived from that. As stated in the preface, the macrostructure is motivated by the needs of the translator. It is difficult to understand the nature of this advantage, however, when comparing the "concepts" within each subdivision. There is no doubt that certain correlations exist within the various subdivisions, e.g. between cell fusion, hybridoma, protoplast fusion. In many other cases a comparison does not reveal any correlation between the "concepts" nested together. This is true of the pages immediately preceding the "concepts" above: hybridization probe, somatic cell hybridization, nucleic acids hybridization, protoplast fusion. Admittedly, the terms are identical or partly mutual, but within the framework of the systematic classification they are not related. There is no subject field relation. Here, we are really dealing with false friends, whose closeness in the macrostructure will confuse the translator rather than help him. The collective terms of hybridization and fusion conceal the differences.

In the case of hybridization probe the molecule in question is a small nucleic acid which is labelled. This piece of nucleic acid can recognise a specific sequence in a larger DNA fragment and hybridise by hydrogen bonds. In this way the probe labels the DNA fragment of interest. Concerning somatic cell hybridisation somatic cells are maintained in culture. By the use of different treatments some of these cells are able to fuse resulting in a new cell which contains the genomes of both mother cells. These hybridoma cells are very useful i.e. to produce monoclonal antibodies. The following term nucleic acids hybridisation brings us back to the area of molecular hybridisation. In this case, two larger single stranded nucleic acids are redoing each other forming a double strand by the use of hydrogen bonds. The process is called 


\section{2}

annealing. Next to this we get the term protoplasts. Here we return to the cell fusion field. The cells involved are most often plant cells which have lost their cell wall by a suitable enzymatic treatment with different cellulases.

It is a matter of doubt whether a translator without a certain knowledge of molecular biology will be able to produce a quality translation. If the translator possesses such knowledge he will be bothered only by the 'systematic classification', which is really not systematic at all. In this case he would be able to find the wanted entryword more quickly if an alphabetic macrostructure had been chosen. In a different dictionary with a more correct systematic structure presumably the translator would still prefer the alphabetic order since each term takes up the space of an entire page and yet he does not obtain several subject field related terms at a glance.

\section{Biotec-Lexinome}

The lexicographical and terminographical reference books within the field of biotechnology have shown that some criticism may be adduced against a large part of the dictionaries. The lexicographical dictionaries for laypeople contain a wide amount of inaccuracies relating to the subject field. Several of them have lexicographical definitions which are intended for semi-experts rather than laypeople. This is also true of the terminographical dictionaries whose systematic macrostructure is not convincing. Furthermore, they are non standardised, as opposed to some of the lexicographical dictionaries for semi-experts. For several lexicographical and all terminographical dictionaries to be useful tools in native-language text production and translation they are not very well designed, especially because of lacking grammatical and collocational information.

How should a dictionary on biotechnology be designed in order to fulfil the requirements of certain user groups? We do not claim to have the only possible answer, but we do claim that it is possible to avoid some of the shortcomings and sources of error described in the previous chapters.

It is not a matter of creed, i.e. between the traditions of lexicography and terminography. In the case of biotechnology some lexicographical dictionaries were definitely more convincing, but that may also have 
been due to the small number of terminographical dictionaries on this topic. It is important that the work be based on a systematic classification which forms the basis of the selection of the empirical basis, the selection of lemmata, the preparation of lexicographical definitions and the preparation of an encyclopaedic section. Since the project implies the preparation of a CD-ROM version the user may have the macrostructure of his own choice, i.e. an alphabetic arrangement, a systematic arrangement or an alphabetic arrangement of lemmata within a certain part of the systematic classification.

The dictionary planned is titled BIOTEC-LEXINOME. "Biotec-" is short for biotechnology, "Lexinome" is a neologism which represents a highly multifunctional dictionary, designed in order to provide information concerning both text-dependent and text-independent problems.

The project is subtitled "Information about Biotechnology with a Special View to Mediators and Decision Makers". In other words, the prime concern is information about biotechnology, an area which, like computer technology, is experiencing rapid growth both in terms of basic and applied research. Even now, 25 years after the breakthrough of biotechnology, many industrial products, including pharmaceuticals and food, are manufactured by means of biotechnological methods. This share is bound to increase in the years to come.

This development does not arouse universal enthusiasm with the general public who tends to see the technology and the possible consequences as being dangerous. This anxiety may be well-grounded, it may also be a natural fear of something that is new and difficult to understand. The fear may be justified in some areas, but not in all. Independently of the attitude of the single man, no rational discussion can be made until there is a certain amount of knowledge on the subject. The present state of things may be explained by the lack of correct and easily comprehensible information. The information available is communicated by professional mediators, i.e. journalists and experts mostly. The information communicated by experts and semi-experts to decision makers in the public sector and the political committees is of particular importance. A large part of the information available is available only in American English which may pose an additional problem, and since American contexts are logically accentuated and referred to, the rest of the English-speaking world may have a problem with this, too. Naturally, it poses a special problem to all other native languages. 
Consequently, dictionaries are primarily aimed at two distinct user types: mediators and decision makers, i.e. politicians and civil servants who make executive decisions concerning biotechnological research and biotechnological products, including those applied in medical treatments. Special attention is also given the needs of the people who in newspapers, on radio or television, in books and brochures inform of these decisions, the ongoing research and the products.

Mediators cover a wide field ranging from journalists at small provincial newspapers to writers of popular-science articles at magazines for semi-experts (such as Scientific American). In the former case some journalists may be considered laypeople, in the latter they would be experts of molecular biology. Journalists at major newspapers may also be experts of molecular biology, though in most cases the members of staff writing about biotechnology will have a scholarly background; these may be regarded as semi-experts. Decision makers who are members of political committees will usually be laypeople. Their advisors at municipal level will usually be semi-experts as they may not necessarily have a molecular biological background and mainly work with environmental issues etc. At government level the advisors will typically be experts who may have problems giving information in a language comprehensible to laypeople.

Thus, the user group described is heterogeneous, covering problems relating to subject field and language for laypeople and semi-experts alike, and linguistic problems for experts. With a user profile such as this BIOTEC-LEXINOME can be applied by user groups without further ado. Most importantly by experts of allied scientific subject fields (such as veterinary medicine, biology, environmental engineering, etc.) and by teachers at secondary schools. Finally, BiOTEC-LEXINOME will be useful to that part of the population who according to the media have reception problems or wish to obtain information at a specialised level of explanation corresponding with that of their own qualifications.

As indicated by the simplified diagram of different levels of competence shown below BIOTEC-LEXINOME is directed at groups 1, 2, and 4: 


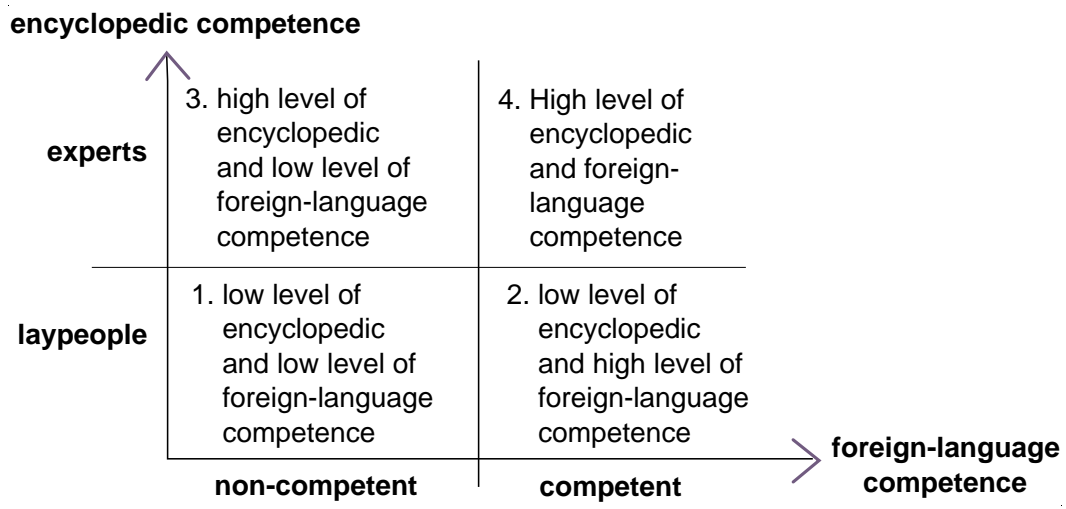

In other words, we are aiming at a multifunctional dictionary which is intended to cover functions $1-7$ as described in ch. 3, i.e. both textdependent functions and one text-independent function. It will comprise the languages (British) English, French, German, Dutch, Spanish, and Danish.

We differentiate between encyclopaedic information (lexicographical definitions) on three levels: interested laypeople, educated laypeople, and semi-experts. This information must be available in each of the six languages above. For this purpose we shall present dictionary examples from the English version in the following. However, these entries do not correspond with the final version, as no illustrations and animations have been included.

First, there is a dictionary encyclopaedic item for the interested layman, i.e. for the user who does not have or does not think he has any basic knowledge of biology and chemistry. The information has been chosen in such a way that molecular biological functions have been focused upon. Information is given about synonyms, where such exist. Moreover, a reference is made to a simple systematic description of biotechnology which may be read as a further introduction to the subject:

gene

the basic unit of inheritance which is transmitted from parents to offspring

$\rightarrow \S 3,21$ 
The interested layman is given a description which more or less presupposes the knowledge obtained with passed A-levels in mathematics and science. The first sentence of the explanation is identical to the explanation for the interested layman. Apart from referring to the systematic classification, terms of special relevance are referred to:

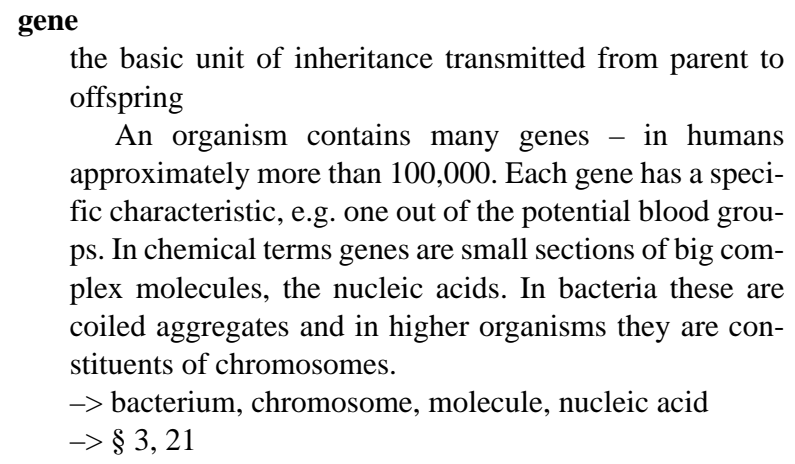

Semi-experts are not necessarily given more detailed encyclopaedic information, but the description is of a more technical nature and it uses a terminology which presupposes a certain basic knowledge of molecular biology:

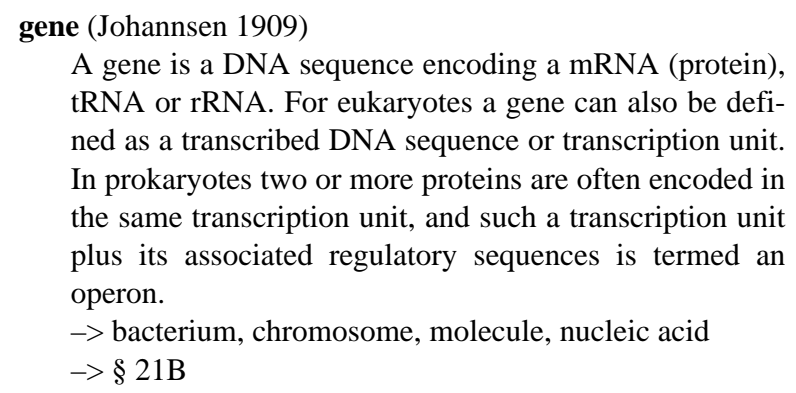

In practise, any user may define himself as an interested layman, an educated layman, or a semi-expert. He may also proceed by the method of trial and error in order to find the level appropriate for the given context on the basis of his own qualifications.

The three dictionary quotations may be regarded as extracts from 18 monolingual encyclopaedias (i.e. 3 x 6 dictionaries corresponding with three levels for six languages). This section of the intended CD-ROM may also be published in form of 18 biotechnological paper dictionaries. 
If compared to paper dictionaries we could say that there will be $5 \mathrm{x}$ 2 bilingual dictionaries, one for each of the language pairs GermanEnglish/English-German, French-English/English-French, SpanishEnglish/English-Spanish, Dutch-English/English-Dutch, and DanishEnglish/English-Danish. Through English the users may go from each of the six languages into the remaining five. Bilingual dictionaries of this sort offer three types of information: grammatical, collocational, and citation examples (authentic examples) which separately or put together may be combined with one of the three levels of encyclopaedic information. Grammatical information consists of word class information and - in the case of irregular inflection or syntactical usage - information on inflection and syntax (cf. Bergenholtz/Pedersen 1994). Collocational information is a central function of both text production and translation (Bergenholtz/Tarp 1994), and it is conspicuously absent in almost all available biotechnological dictionaries. Information on citation examples may be understood as implicit information on grammar and collocation, it may also contain further encyclopaedic information, but in no way is it to be regarded as definitions. The following examples correspond with the equivalent passages in KAUFMANN/ BERGENHOLTZ et al.:

$$
\begin{aligned}
& \text { gene gen } \mathrm{m} \\
& \mathbf{\Delta} \text { ancestral } \sim \text { ancestral; a cancer causing } \sim \text { un } \sim \text { cau- } \\
& \text { sante de cáncer; a chimeric } \sim \text { un } \sim \text { quimérico; determine } \\
& \text { the precise boundaries of a } \sim \text { determinar los límites pre- } \\
& \text { cisos de un } \sim \text {; insert a } \sim \text { insertar un } \sim \text {; a } \sim \text { library una } \\
& \text { biblioteca de } \sim \text { es; locate a } \sim \text { localizar un } \sim \text {; a regulato- } \\
& \text { ry protein una proteína reguladora de } \sim \text { es; structural } \sim \\
& \text { estructural } \\
& \bullet \text { In the case of the AIDS virus the protein might stimula- } \\
& \text { te the transcription of viral genes (and perhaps the viral or } \\
& \text { host gene for soluble suppressor factor) while either inhi- } \\
& \text { biting genes that stimulate replication of the T4 host cell } \\
& \text { or activating genes that turn off cell division. }
\end{aligned}
$$

In connection with the dictionary section BIOTEC-LEXINOME will have as mentioned previously - two different introducktions to biotechnology in each of the six languages, one for laypeople and one for semiexperts. They will serve both as an introduction to the field and as a reference from the dictionary articles for the description of systematic correlations. Again, each user may select the knowledge level of his own choice, in this case the choice of two levels only. 
Furthermore, BIOTEC-LEXINOME will include a survey of biotechnology-related legislation in the individual EU-countries. This survey will be rendered in the native language of the country concerned and in English. Moreover, there will be a complete presentation of international agreements.

Finally, we anticipate minor contributions from critics and supporters of biotechnology from each individual country. Public debate often differs widely in the individual countries and may only be relevant for the country in question. Consequently, these contributions will not be translated, but only presented in the individual native languages. This part of BIOTEC-LEXINOME must be viewed in connection with the fact that just communicating "naked facts" is not adequate for people to rationally make up their minds about socially controversial issues. The managing director of Unilever has put it quite clearly: "Let me confront you with the conclusion which Unilever has reached internally: For food, this new technology can only be introduced in the market place with the consent and support of the major public opinion leaders" (de Vet 1993:83). More knowledge does not, however, lead to a higher degree of acceptance; things are more complicated than that. Things are not the other way around either, but more knowledge does lead to changes in attitude. A greater amount of knowledge leads to a higher degree of acceptance and also to a higher degree of scepticism (Eurobarometer 1991). Increased knowledge is a precondition of discussing on a higher factual level and it permits the fear of the unknown to be transformed into an attitude or fear of a known, but specific dangerous development (Marlier 1992:67-70). This is not only true for laypeople (level 0-4), but also for semi-experts (level 5-6), and even where experts are concerned (level 7) the total of sceptics exceed that of the laypeople of levels 0-3.

$\begin{array}{lll}\text { Knowledge Optimists } & \text { Pessimists } \\ 1 & 6 \% & 5 \% \\ 2 & 3 \% & 4 \% \\ 3 & 5 \% & 6 \% \\ 4 & 10 \% & 14 \% \\ 5 & 16 \% & 21 \% \\ 6 & 16 \% & 17 \% \\ 7 & 15 \% & 15 \% \\ 8 & 29 \% & 18 \%\end{array}$


All in all, BiOTEC-LEXINOME will be able to contribute to factually relevant information on different levels, it will contribute to a standardisation of specialised language where available extensive studies do not exist, and it can be used as a tool in text production and translation.

\section{LSP Lexicography or Terminography}

In chapter 1 we expressed general scepticism as to the durability of the criteria established by terminologists in order to distinguish between lexicographical and terminographical reference books. In conclusion, we will support this scepticism by comparing the 14 criteria mentioned in chapter 1 to a special case, namely the structure and content of some of the biotechnological dictionaries included in chapters 4-6.

Criterion (1) applied to reception dictionaries for laypeople implies that they must be regarded as lexicographical dictionaries since their object is not exclusively LSP language. The remaining dictionaries examined had to be regarded as potential terminographical dictionaries.

If by criterion (2) is meant the involvement of experts, reception dictionaries are not terminographical. However, the criterion would apply to most of the other dictionaries mentioned, perhaps with the exception of BIOTECHNOLOGY GLOSSARY whose systematic macrostructure (criterion 10 and 12) would be an obvious candidate for a projection to terminographical reference books. Still, this is not the case either, since in its choice of defining quotations the dictionary reveals such pronounced lacks that one must doubt whether experts have actually been involved in the entire process of planning and preparing the dictionary at all. Furthermore, the macrostructure of this dictionary is only partly systematic, since in several places it contains an expression-related arrangement of lemmata which does not correspond with the subject field universe (cf. ch. 6). Besides, it differs from the purely systematic structure in starting with a passage containing biotechnological basic terms which in principle should have been included in the other systematic passages. BIOTEC-LEXINOME will satisfy the requirement for systematic macrostructure to a larger extent, as the intended CD-ROM version will be able to produce the single articles in an alphabetic or a systematic order.

Most of the dictionaries examined are available in the form of paper dictionaries (criterion 3), including BIOTECHNOLOGY GLOSSARY, where- 
as BIOTEC-LEXINOME - as mentioned above - is planned exclusively as a CD-ROM version. Several of the dictionaries, including BiOTECLEXINOME, have been prepared for experts or semi-experts (criterion 4), not Biotechnology Glossary, however, which is intended for laypeople only. None of the dictionaries examined have been designed exclusively as an aid for text production (criterion 5), but several multifunctional dictionaries, including BIOTEC-LEXINOME, aim at being an aid for both text reception and text production. Consequently, these three criteria prove rather unsuccessful. Only BIOTEC-LEXINOME may be said to meet the terminographical requirements mentioned, whereas the translation dictionary BIOTECHNOLOGY GLOSSARY in this context must be characterised as a lexicographical reference book - provided that you wish to accept the attempt to separate made by terminologists.

Several of the reception dictionaries give etymological information (criterion 6), whereas what the biotechnological dictionaries are concerned only Rieger et al. give references to the first use of the term in question within genetic LSP. Such information may be extremely relevant to the understanding of a term; it should not be excluded and is intended to form part of BIOTEC-LEXINOME.

Most general language dictionaries are primarily descriptive and consequently according to criterion (7) lexicographical. This is also true of BIOTECHNOLOGY GLOSSARY which often gives several equivalents without standardising recommendations. In principle, most of the remaining dictionaries must be considered to be primarily prescriptive, as new terms have been constructed and only one of several possible terms has been chosen as the only information given. This is also true of BioteC-LeXinOME. As for polysemous lexemes (criterion 9) we may establish beyond all doubt that polysemy - or rather homonymy - on the whole only occurs in connection with abbreviations (e.g. $a$ for adenine and adenosine) in the biotechnological dictionaries examined which in this respect all fulfil the terminographical requirement.

As for criterion (4) we wish to comment that it is difficult to imagine how the large amount of dictionaries for semi-experts could have been prepared by using linguistic methods, as most of them have been prepared by biotechnological experts without any help from linguists. All in all, we believe that all of the purely biotechnological reference books describe concept relations and projections and consequently may all be defined as terminographical judging from this criterion. 
Somewhat surprisingly we have to establish the fact that the dictionary which fulfils the highest number of the 14 terminographical criteria is BIOTEC-LEXINOME, whose authors do not see themselves as terminographers, but very much as lexicographers. If you exclude certain different choices of terms used in describing the lexicographical and the terminological theory, this projection is particularly valid. All things considered, we will reject the relevance of a distinct conflict of interests between lexicographical and terminographical reference books. It is more relevant to separate the reference books which contain wrong or inaccurate information, which lack substantial information for certain purposes, and which do not or only slightly give standardising references. It should be possible to avoid such lacks of quality in any reference book, independent of whether the author of the work defines himself as a terminographer or as a lexicographer.

Hand in hand with the demand for quality comes the necessary regard for different user groups and user situations. In this particular respect the authors of this article and of BIOTEC-LEXINOME are bound to regard themselves as lexicographers, taking into account - as opposed to terminographers - certain genuine purposes (criterion 4). This choice does not necessarily involve the reduction of potential user groups. It is possible to give the same kind of information in more ways than one within the same dictionary so that the explanations correspond with the qualifications of the single user group (cf. ch. 6).

\section{Literature}

\subsection{Dictionaries}

Agriculture $=$ Alan Stephens (ed.): Dictionary of Agriculture: Middlesex: Peter Collin 1990.

BABEL et al. = Wolfgang Babel/Monica Hagemann/Wolfgang Höhne: Wörterbuch Biotechnologie Englisch-Deutsch/Dictionary of Biotechnology English-German. Thun, Frankfurt/M.: Verlag Harri Deutsch 1989.

BIOTEC-LeXINOME $=$ Henning Bergenholtz/Henri Bejoint/Uwe Kaufmann/Dean Madden/Willy Martin/Rigomar Rieger/Rosa de la Viesca: Biotec-Lexinome. Encyclopaedic and Linguistic Information about Biotechnology with a Special View to Mediators and Decision Makers. Project Proposal. Århus: Handelshøjskolen i Århus 1996.

Biotechnology From A to $\mathrm{Z}=$ William Bains: Biotechnology from A to Z. Introduction by G. Kirk Raab. Oxford/New York/Tokyo: Oxford University Press 1993. 
BIOTECHNOLOGY GlossARY = Biotechnology Glossary. Glossaire de Biotechnologie . etc. English français deutsch italiano nederlands dansk español português ellhnika. London/New York: Elsevier 1990.

BRAND = Karl Brand: Taschenlexikon der Biochemie und Molekularbiologie. Heidelberg/Wiesbaden: Quelle \& Meyer 1992.

BROCKHAUS/WAHRIG = Brockhaus-Wahrig. Deutsches Wörterbuch in sechs Bänden . Hrsg. von Gerhard Wahrig, Hildegard Krämer, Harald Zimmermann. Wiesbaden: Brockhaus / Stuttgart: Deutsche Verlagsanstalt 1980-1984.

CoBulLD = Collins CoBulLD English Language Dictionary. Editor in Chief: John Sinclair, Managing Editor: Patrick Hanks. London/Glasgow: Collins 1995.

Coombs = James Coombs: Macmillan Dictionary of Biotechnology. Second Ed. London/Basingstoke: Macmillan 1992.

DUDEN-GWB = Duden. Das große Wörterbuch der deutschen Sprache in acht Bänden. Hrsg. u. bearb. vom Wissenschaftlichen Rat und den Mitarbeitern der Dudenredaktion unter Leitung von Günther Drosdowski. Mannheim/Wien/Zürich: Dudenverlag 1993-1995.

ENCARTA = Encarta 96. Encyclopedia . Microsoft 1996.

Glossary of Biotechnological TeRMS = Hans Georg W. Leuenberger/Bertrand Nagel/Heinz Kölbl (eds.): A Multilingual Glossary of Biotechnological Term in English, French, German, Japanese, Portuguese, Russian, Spanisch (IUPAC Recommendations). Basel: Helvetica Chimica Acta/Weinheim usw: VCH 1995.

GROLIER = Grolier Multimedia Encyclopedia . Grolier 1995.

HARRAP = Harrap's Essential English Dictionary. Managing Editor: Elaine Higgleton, Senior Editor: Anne Seaton. Edingburgh: Harrap 1995.

Heritage ScIENCE = Robert K. Barnhart: The American Heritage Dictionary of Science. Bonston/New York: Houghton Mifflin 1986.

KaUfMAnN/BergenholTz = Uwe Kaufmann/Henning Bergenholtz: Genteknologisk ordbog. Dansk-engelsk/engelsk-dansk molekylarbiologi og DNA-teknologi. København: Gad 1992.

KaUfMANN/Bergenholtz et al. = Uwe Kaufmann/Henning Bergenholtz in Cooperation with Bjarne Stumman/Sven Tarp/Francisco Planas Guiral/Laura de la Rosa Marabet/Nelson la Serna Torres/Gladys la Serna Miranda: Diccionario Enciclopédico de Ingeniería Genética Español-Inglés/Inglés-Español. (in prep.)

KUCERA = Kucera, Antonín: The Compact Dictionary of Exact Science and Technology. English-German. 2. ed. Wiesbaden: Oscar Brandstetter Verlag GmbH \& Co. KG 1989.

LH $=L \& H$ Compact Teknisk Ordbog dansk-engelsk. Redigeret af Thomas Nielsen. København: Langkilde \& Høedt Forlag 1993.

LONGMAN Culture $=$ Longman Dictionary of English Language and Culture. Harlow: Longman 1992. 
OlIVER/WARD = Stephen G. Oliver/John M. Ward: Wörterbuch der Gentechnik, Stuttgart: Gustav Fischer Verlag 1988.

OXFord EnCyClopedic Dictionary = The Oxford Encyclopedic English Dictionary . Ed. by Joyce M. Hawkins and Robert Allen. Oxford: Clarendon Press 1991.

RIEGER et al. = Rigomar Rieger/Arnd Michaelis/Melvin Green: Glossary of Genetics . Classical and Molecular. 5. ed. Berlin/Heidelberg/New York/London/Paris/Tokyo/ Hong Kong/Barcelona/Budapest: Springer-Verlag 1991.

ScHMID/FuKUI = Rolf Schmid/Saburo Fukui: Dictionary of Biotechnology. Berlin etc.: Springer 1986.

SCHUMACHER = Helmut Schumacher (Hrsg.) (1986): Verben in Feldern, Valenzwörter buch zur Syntax und Semantik deutscher Verben. Berlin/New York: Walter de Gruyter.

WALKER/Cox = John M. Walker/Michael Cox: The Language of Biotechnology. A Dictionary of Terms. With Allan Whitaker as contributor. Washington DC: ACS Professional Reference Book/American Chemical Society 1988.

\subsection{Secondary literature}

Andersen, Axel (1990): Veje til viden. Håndbøger og andre informationskilder. Danmarks Biblioteksskole 1990.

Bergenholtz, Henning (1995a): Wodurch unterscheidet sich Fachlexikographie von Terminographie? In: Lexicographica 11, 37-46.

Bergenholtz, Henning (1995b): Leksikografi. Hvad er det? In: Åsta Svararsdóttir/ Gudrun Kvaran/Jón Hilmar Jónsson (red.): Nordiske studier i leksikografi 3. Rapport fra Konference om leksikografi i Norden. Reykjavik 7.-10. juni 1995. Reykjavik: Nordisk forening for leksikografi, 37-49.

Bergenholtz, Henning (1996): Grundfragen der Fachlexikographie. In: Martin Gellerstam/Jerker Järborg/Sven-Göran Malmgren/Kerstin Norén/Lena Rogström/ Catarina Röjder Papmehl (eds.): Euralex '96. Proceedings I-II. Papers submitted to the Seventh EURALEX International Congress on Lexicography in Göteborg, Sweden. Göteborg: Göteborg University, 731-758.

Bergenholtz, Henning/Pedersen, Jette (1994): Grammar in bilingual LSP dictionaries, with a special view to technical English. In: Burkhard Schaeder/Henning Bergenholtz (Hrsg.): Fachlexikographie. Fachwissen und seine Repräsentation in Wörterbüchern. Tübingen: Narr, 351-383.

Bergenholtz, Henning/Tarp, Sven (1994): Mehrworttermini und Kollokationen in Fachwörterbüchern. In: Burkhard Schaeder/Henning Bergenholtz (Hrsg.): Fachlexikographie. Fachwissen und seine Repräsentation in Wörterbüchern. Tübingen: Narr, 385-419.

Dubois, Claude (1979): La spécificité de la définiton en terminologie (par comparaison avec la définition en lexicographie). In: Actes du sixiéme colloque international de terminologie. Pointe-au-Pic (Québec) du 2 au 7 octobre 1977. Québec, 45-59. 
Eurobarometer = Eurobarometer 35.1. "Biotechnology" for the Commission of the European Communities. Directorate - General Science, Research, Development "Cube"-Biotechnology Unit by INRA (EUROPE0 European Coordination Office SA/NV. June 1991.

Felber, Helmut/Budin, Gerhard (1989): Terminologie in Theorie und Praxis. Tübingen: Narr.

Frandsen, Lene (1979): Terminologi og Leksikologi. Forskelle og Ligheder. København: Handelshøjskolen i København.

Joly, Hubert (1986): Itinéaire d'un lexicographe de fortune. In: Language Monthly. September '86, 12-14.

Kalverkämper, Hartwig (1990): Der Begriff der »Fachlichkeit« im modernen Italienischen. Lexikalische Systematik und textuelle Integration. In: Quardini di Semantica. Rivista internazionale di semantica teorica e applicata 11, 79-115.

Kaufmann, Uwe (1997): Fachwörterbücher mit und ohne Mitwirkung von Lexikographen, Fachexperten und Sprachexperten. In: Arne Zettersten/Jens Erik Mogensen/Viggo Hjørnager Pedersen (eds.): Symposium on Lexicography VIII. Proceedings of the Eigthth International Symposium on Lexicography May 2-5, 1996 at the University of Copenhagen. (in print)

Maidahl Christiansen, Lisbet/Duvå, Grete/Laursen, Anna-Lise (1994): Das Translationswörterbuch für Fachsprachen. Ein integriertes Konzept. In: Burkhard Schaeder/Henning Bergenholtz (Hrsg.): Das Fachwörterbuch. Fachwissen und seine Repräsentation in Wörterbüchern. Tübingen: Narr, 269-284.

Marlier, Eric 1992: Eurobarometer 35.1. Opinions of Europeans on biotechnology in 1991. In: biotechnology in public a review of recent research. Ed. by John Durant. London: Science Museum, 52-108.

Nielsen, Sandro (1995): Alphabetic macrostructure. In: Henning Bergenholtz/Sven Tarp (eds.): Manual of Specialised Lexicography. Preparation of LSP dictionaries problems and suggested solutions. Amsterdam: Benjamins, 190-195.

Pedersen, Jette (1995): Systematic classification. In: Henning Bergenholtz/Sven Tarp (eds.): Manual of Specialised Lexicography. Preparation of LSP dictionaries problems and suggested solutions. Amsterdam: Benjamins, 83-90.

Picht, Heribert (1985): Leksikografi - Terminografi. In: Nordisk terminologikursus 2. Bind 1, 351-372.

Picht, Heribert (1992): Grænseflader mellem terminologi og vidensteknik. In: Bertha Toft (Hrsg.): Proceedings af 2. nordisk symposium om Terminologi EDB \& Vidensteknik. [Kolding], 22-33.

Rey, Alain (1979): Définition de la terminologie en tant que discipline lingistique autonome: état de la question. In: Actes du sixiéme colloque internaitoanl de terminologie. Pointe-au-Pic (Québec) du 2 au 7 octobre 1977. Québec, 229-257.

Riggs, Fred W. (1989): Terminology and Lexicography: Their Complementarity. In: International Journal of Lexicography 2, 89-110. 
Roald, Jan 1987: Leksikografi og terminologi: en sammenligning. In: Tove Jacobsen/ Jan Roald (eds.): Flerspråklig leksikografi og terminologi. Seminarrapport Bergen 22.-23. mai 1987. Bergen: Universitetet i Bergen, 3-13.

Sager, Juan C. (1990): A Practical Course in Terminology Processing. Amsterdam: Benjamins.

Schaeder, Burkhard (1994): Zu einer Theorie der Fachlexikographie. In: Burkhard Schaeder/Henning Bergenholtz (Hrsg.): Fachlexikographie. Fachwissen und seine Repräsentation in Wörterbüchern. Tübingen: Narr, 11-41.

Svensén, Bo (1992): Terminologi och lexikografi. In: Terminologiläran och dess relationer till andra områden. Nordisk forskarkurs i Mariehamn, Åland, september 1990. Stockholm: NordTerm, 97-122.

Thomas, Patricia (1993): Choosing headwords from language-for-special-purposes (LSP) collocations for entry into a terminology data bank (term bank). In: Helmi B. Sonneveld/Kurt L. Loening (eds.): Terminology. Applications in interdisciplinary communication. Amsterdam: Benjamins, 43-68.

Vet, Bernard de (1993): Public Acceptance: Dialogue with Opinion Leaders. In: Brian Ager (ed.): BioEurope '93. Proceedings. International Conference and Exhibition. Brussels 1-6 June 1993. Brussel: Senior Advisory Group on biotechnology (SAGB), 83-91.

Wiegand, Herbert Ernst (1988): Was eigentlich ist Fachlexikographie? Mit Hinweisen zum Verhältnis von sprachlichem und enzyklopädischem Wissen. In: H.H. Munske et al (Hrsg.): Deutscher Wortschatz. Lexikologische Studien. Ludwig Erich Schmitt zum 80. Geburtstag von seinen Marburgern Schülern. Berlin/New York: de Gruyter, 729-790.

Wiegand, Herbert Ernst (1994): Zur Unterscheidung von semantischen und enzyklopädischen Daten in Fachwörterbüchern. In: Burkhard Schaeder/Henning Bergenholtz (Hrsg.): Fachlexikographie. Fachwissen und seine Repräsentation in Wörterbüchern. Tübingen: Narr, 103-132.

Wiegand, Herbert Ernst (1995): Der kulturelle Beitrag der Lexicographie zur Umgestaltung Osteuropas. In: Lexicographica 11, 210-218.

Wüster, Eugen Wüster (1936): Wörterbücher der Technik. In: Wörter und Sachen 17, 164-173.

Wüster, Eugen (1985): Einführung in die allgemeine Terminologielehre und terminologische Lexikographie. 2. Aufl. Kopenhagen. (1. ed. Wien/New York: Springer 1979) 
126 
